\title{
Correlation of Endostatin and Tissue Inhibitor of Metalloproteinases 2 (TIMP2) Serum Levels With Cardiovascular Involvement in Systemic Sclerosis Patients
}

\author{
Bożena Dziankowska-Bartkowiak, ${ }^{1}$ Elżbieta Waszczykowska, ${ }^{1}$ Anna Zalewska, ${ }^{2}$ and Anna Sysa-Jędrzejowska ${ }^{2}$ \\ ${ }^{1}$ Division of Immunodermatology, Medical University of Lodz, Krzemieniecka 5, 94-017 Lodz, Poland \\ ${ }^{2}$ Department of Dermatology, Medical University of Lodz, Krzemieniecka 5, 94-017 Lodz, Poland
}

Received 14 January 2005; accepted 11 April 2005

\begin{abstract}
Fibrosis of oesophagus, lungs, heart, and kidney in the course of systemic sclerosis (SSc) may lead to dysfunction of the above organs or even patients death. Recent studies point out the role of angiogenesis and fibrosis disturbances in the pathogenesis of SSc. Heart fibrosis is one of the most important prognostic factors in SSc patients. So, the aim of our study was to examine cardiovascular dysfunction in SSc patients and its correlation with serum levels of vascular endothelial growth factor (VEGF), endostatin, and tissue inhibitor of metalloproteinase 2 (TIMP2). The study group comprised 34 patients (19 with limited scleroderma (1SSc) and 15 with diffuse scleroderma (dSSc)). The control group consisted of 20 healthy persons, age and sex matched. Internal organ involvement was assessed on the basis of specialist procedures. Serum VEGF, endostatin, and TIMP2 levels were evaluated by ELISA. We found cardiovascular changes in 15 patients with SSc ( 8 with 1 SSc and 7 with dSSc). The observed symptoms were of different characters and also coexisted with each other. Higher endostatin serum levels in all systemic sclerosis patients in comparison to the control group were demonstrated $(P<.05)$. Also higher serum levels of endostatin and TIMP2 were observed in patients with cardiovascular changes in comparison to the patients without such changes $(P<.05)$. The obtained results support the notion that angiogenesis and fibrosis disturbances may play an important role in SSc. Evaluation of endostatin and TIMP2 serum levels seems to be one of the noninvasive, helpful examinations of heart involvement in the course of systemic sclerosis.
\end{abstract}

\section{INTRODUCTION}

Systemic sclerosis (sclerodermia sistemica, scleroderma-SSc) is a chronic, multifactorial disease which was first described by Goetz [1]. Pathogenesis of this disease still remains not fully elucidated. The disease can run either a chronic or violent course which depends on the degree of internal organs dysfunction. This dysfunction can even lead to patients death $[2,3]$. Literature data point out that small and large blood vessel disturbances and fibrosis development play a key role in connective tissue changes of immunological character [4].

In healthy tissues angiogenesis does not take place because of equilibrium levels of proangiogenic and antiangiogenic factors. The following factors are known to trigger angiogenesis, that is, vascular endothelial growth factor (VEGF), basic fibroblast growth factor (bFGF), and

Correspondence and reprint requests to Bożena DziankowskaBartkowiak, Division of Immunodermatology, Medical University of Lodz, Krzemieniecka 5, 94-017 Lodz, Poland; anuciazalewska@hotmail.com interleukin-18 (IL-18) $[5,6,7]$, whereas endostatin, TGF$\beta$, TNF- $\alpha$, interleukin-10 (IL-10), as well as tissue inhibitor of metalloproteinases 1, 2, 3 (TIMP1, 2, 3) have antiangiogenic activity [5]. Literature data reporting inhibitory effects on angiogenesis exerted by monocytes and lymphocytes obtained from systemic sclerosis patients could further support the importance of angiogenesis disturbances in the development of systemic sclerosis $[8,9]$.

Impairment of collagen I, collagen III, collagen V, collagen VI, collagen VII synthesis in SSc leads to skin and internal organ fibrosis. Recent research data underline the important role of proteases in extracellular matrix degradation, including collagen, in the course of this disease [10]. It is worth pointing out that matrix metalloproteinases (MMPs) belong to the group of proteases. Those enzymes activity depends on zinc and calcium ions presence. MMPs are synthesized and released by fibroblasts, monocytes, granulocytes, T lymphocytes, dendritic cells, macrophages, endothelial cells, microglia, epithelial cells, myocytes, and astrocytes [11]. Tissue inhibitors of proteinases (TIMPs) are suggested to play a more important role in fibrosis development than proteolytic enzymes. What is more, TIMPs are synthesized by the same cells as 
their proteolytic enzymes [12]. They exert an inhibitory effect on metalloproteinases activation and further also on active forms of those enzymes [13]. Up till now, four TIMPs have been described, out of which the role of three has been fairly well elucidated, that is, TIMP1, 2, and 3 [14]. Homeostasis disturbances between MMPs and their tissue inhibitors could be responsible for changes in extracellular matrix composition.

Heart involvement could be one of the most important prognostic factors in the course of SSc [15]. Heine, already in 1926, was the first scientist to describe heart disturbances in SSc [16]. It should be noted that cardiovascular changes could develop at any stage of the disease. However, clinical symptoms have not been characteristic and manifest fairly late thus leading to late diagnosis and subsequent delay in proper treatment [17]. The most common complaints reported by the patients with heart involvement are palpitations, dyspnoea, fatigability, and vague pain in the chest [18]. Myocardial fibrosis may lead to conduction disturbances and arrhythmia. Exudative pericarditis has been also reported in the course of SSc [19].

Myocardial ischaemia, resulting from coronary vessels spasms, observed in SSc patients may resemble peripheral Raynaud's phenomenon [15]. In SSc patients, more often than in the general population, morphological changes of heart structures, specially of the mitral valve, are observed [20]. Employment of echocardiography, spiroergometry, perfusion scintigraphy of the myocardium, 24hour heart rhythm monitoring allow to detect clinically "silent" changes $[21,22]$.

The aim of our study was to evaluate cardiovascular changes in SSc patients and assess serum levels of VEGF, endostatin, and TIMP2 in those patients.

\section{MATERIALS AND METHODS}

The study involved 34 SSc patients, 26 women and 8 men, of age range 16-69 years. In our group 15 patients presented diffuse form (dSSc) (mean $45.4 \pm 12.5$ years) and 19 limited SSc (1SSc) (mean age $50.7 \pm 13.3$ years). All the patients were diagnosed according to American College of Reumatology (ACR) criteria [23].

Because of the illness course, all dSSc subjects were on disease-modifying drugs, that is, cyclophosphamide (50 mg daily), prednisone (15-20 mg daily) or combination of both agents in the same doses as in monotherapies (treatment duration: 3-168 months, mean: $27 \pm 48$ months). The remaining 19 patients never received the above medication. Patients from both subgroups were treated with nifedipine (10 mg daily) and vitamin E (400 mg daily) for at least 5 months.

The degree of skin sclerosis was assessed using the total skin score (TSS) according to Kahaleh et al (0-66 points) [24].

Functional evaluation of four internal organs and systems, that is, oesophagus, cardiovascular system, joint and bone system, and lungs was performed by oesophagal scintigraphy, 24-hour ECG monitoring (3-channel Oxford Medilog Excel-2), Doppler echocardiography (HP 2500 apparatus), X-ray examination of feet and hand bone, X-ray chest examination, and DLCO (diffusing capacity of the lung for carbon monoxide) (expressed in percentages of the predicted value; pulmonary changes were diagnosed when DLCO was below $80 \%$ of the predicted value).

Blood was collected in the morning into the pyrogenfree tubes and stored in $-20^{\circ} \mathrm{C}$ until further evaluated. VEGF levels were measured in 33 patients (19 with 1SSc and 14 with dSSc) and endostatin in 30 patients (16 with ISSc and 14 with dSSc). The control group consisted of 20 healthy persons (19 female, 1 male; aged 25-64 years, mean age: $46.3 \pm 13.2$ years). TIMP2 serum levels were measured in 21 patients ( 9 with $1 \mathrm{SSc}$ and 12 with dSSc) and 10 healthy persons ( 8 women and 2 men; aged 20-64 years, mean age: $47.2 \pm 12$ years).

VEGF, endostatin, and TIMP2 serum levels were evaluated by enzyme immunoassay technique (ELISA) (Quantikine R\&D Systems Inc, Minneapolis Minn; Oncogene Research Products, Boston, Mass; Amersham, Pharmacia Biotech, England, UK). Detection sensitivity of the examined cytokines was $9.0 \mathrm{pg} / \mathrm{mL}$ for VEGF, $1.953 \mathrm{ng} / \mathrm{mL}$ for endostatin, and $0.011 \mathrm{ng} / \mathrm{mL}$ for TIMP2. This TIMP-2 assay detects approximately 50\% of recombinant human TIMP-2 when complexed with recombinant human active MMP-9 in a 1:1 molar ratio. rhMMP-2 cross-reacts $0.002 \%$ at concentrations greater than $2.5 \mathrm{ng} / \mathrm{mL}$.

Antinuclear antibody titres were examined by indirect immunofluorescence test on HEp-2 cells.

All patients and individuals from the control group gave their informed consent to participate in our study according to the Bioethic Committee of Medical University of Lodz requirements.

\section{STATISTICAL ANALYSIS}

The obtained results were expressed as mean, maximum, minimum, and median values together with standard deviation (SD). Numerical variables distribution was assessed by Shapiro-Wilk test. Mann-Whitney, CochranCox, and two independent sample tests were employed for comparison of mean or median values. Correlations between serum levels of VEGF, endostatin and heart involvement were evaluated by Fisher precisely test with correlation coefficient Q. A $P$ value less than .05 was considered to be statistically significant.

\section{RESULTS}

Clinical characteristics of the patients are presented in Table 1 .

We revealed disturbances in different internal organs, that is, oesophagus in $26 / 34$ SSc patients (15 with ISSc and 
TABLE 1. Clinical characteristics of the examined groups. (A) denotes the control group for the examined angiogenesis factors; (B) denotes the control group for the examined TIMP2; SD denotes the standard deviation; $n$ is the number of patients; TSS is the total skin score; ANA denotes antinuclear antibodies. $*$ denotes statistically significant differences in comparison between limited and diffuse systemic sclerosis $(P<.05) . * *$ denotes statistically significant differences in comparison to the control group $(P<.05)$. Oesophagal changes included oesophagal scintigraphy disturbances: swallowed passage in the lower and/or central part of the oesophagus. Cardiovascular abnormalities included tendency to tachyarhythmias, lower potentials of different parameters describing variability of cardiac rhythm or conduction system abnormalities, ventricular arrhythmia, silent ischaemic episodes, diastolic left ventricular disturbances, and valvular lesions. Osteoarticular changes included changes in osteoarticular system: juxta-articular demineralisation, joint space narrowing in digits. Interstitial lung disease included DLCO $<80 \%$ of predicted value with or without X-ray chest changes: symmetrical fibrosis of the lung base and "honeycomb" picture.

\begin{tabular}{|c|c|c|c|c|c|}
\hline Parameter & $\begin{array}{l}\text { Statistical } \\
\text { parameters }\end{array}$ & $\begin{array}{c}\text { Systemic } \\
\text { sclerosis (SSc) } \\
n=34\end{array}$ & $\begin{array}{c}\text { Limited systemic } \\
\text { sclerosis (1SSc) } \\
n=19\end{array}$ & $\begin{array}{l}\text { Diffuse systemic } \\
\text { sclerosis }(\mathrm{dSSc}) \\
n=15\end{array}$ & $\begin{array}{l}\text { Control group } \\
\qquad \begin{array}{l}\text { (A) } n=20 \\
\text { (B) } n=10\end{array}\end{array}$ \\
\hline Age (y) & $\begin{array}{l}\text { Range } \\
\text { (mean) }\end{array}$ & $\begin{array}{c}16-70 \\
(48)\end{array}$ & $\begin{array}{c}27-70 \\
(50)\end{array}$ & $\begin{array}{c}16-64 \\
(45)\end{array}$ & $\begin{array}{l}\text { (A) } 25-64 \\
(46) \\
\text { (B) } 20-64 \\
(47)\end{array}$ \\
\hline $\operatorname{Sex}(F / M)$ & 一 & $26 / 8$ & $18 / 1$ & $8 / 7$ & $\begin{array}{l}\text { (A) } 19 / 1 \\
\text { (B) } 8 / 2\end{array}$ \\
\hline $\begin{array}{l}\text { Cardiovascular } \\
\text { abnormalities }\end{array}$ & - & $15 / 34$ & $8 / 19$ & $7 / 15$ & \\
\hline $\begin{array}{l}\text { Oesophagus changes } \\
\text { Interstitial lung disease } \\
\text { Osteoarticular changes } \\
\text { ANA }\end{array}$ & - & $\begin{array}{l}26 / 34 \\
20 / 34 \\
27 / 34 \\
34 / 34\end{array}$ & $\begin{array}{l}15 / 19 \\
10 / 19 \\
15 / 19 \\
19 / 19\end{array}$ & $\begin{array}{l}11 / 15 \\
10 / 15 \\
12 / 15 \\
15 / 15\end{array}$ & \\
\hline TSS & $\begin{array}{c}\text { Mean } \pm \text { SD } \\
\text { Median } \\
\text { Range }\end{array}$ & $\begin{array}{c}28.1 \pm 13.8 \\
25.0 \\
12.0-53.0 \\
\end{array}$ & $\begin{array}{c}17.8^{*} \pm 5.1 \\
17.0 \\
12.0-30.0 \\
\end{array}$ & $\begin{array}{c}41.3^{*} \pm 9.0 \\
44.0 \\
26.0-53.0 \\
\end{array}$ & \\
\hline $\begin{array}{l}\text { VEGF } \\
(\mathrm{pg} / \mathrm{mL})\end{array}$ & $\begin{array}{l}\text { Mean } \pm \mathrm{SD} \\
\text { Median } \\
\text { Range }\end{array}$ & $\begin{array}{c}194.0 \pm 196.8 \\
138.2 \\
0.0-836.4 \\
n=33\end{array}$ & $\begin{array}{c}219.5 \pm 228.4 \\
138.2 \\
0.0-836.4 \\
n=19\end{array}$ & $\begin{array}{c}159.6 \pm 144.6 \\
134.3 \\
0.0-455.6 \\
n=14\end{array}$ & $\begin{array}{c}271.2 \pm 201.0 \\
286.4 \\
23.7-708.5 \\
n=20\end{array}$ \\
\hline $\begin{array}{l}\text { Endostatin } \\
\text { (ng/mL) }\end{array}$ & $\begin{array}{c}\text { Mean } \pm \text { SD } \\
\text { Median } \\
\text { Range }\end{array}$ & $\begin{array}{c}113.6 \pm 60.7^{* *} \\
107.2 \\
13.6-261.2 \\
n=30\end{array}$ & $\begin{array}{c}101.9 \pm 53.1 \\
101.4 \\
13.6-209.6 \\
n=16\end{array}$ & $\begin{array}{c}127.1 \pm 67.8^{* *} \\
124.2 \\
18.0-261.2 \\
n=14\end{array}$ & $\begin{array}{c}73.6 \pm 25.9 \\
77.8 \\
18.0-110.4 \\
n=20\end{array}$ \\
\hline $\begin{array}{l}\text { TIMP2 } \\
\text { (ng/mL) }\end{array}$ & $\begin{array}{c}\text { Mean } \pm \text { SD } \\
\text { Median } \\
\text { Range }\end{array}$ & $\begin{array}{c}80.0 \pm 31.5 \\
\quad 65.0 \\
38.6-131.9 \\
n=21\end{array}$ & $\begin{array}{c}79.8 \pm 32.5 \\
61.0 \\
52.6-128.9 \\
n=9\end{array}$ & $\begin{array}{c}80.2 \pm 32.2 \\
\quad 65.1 \\
38.6-131.9 \\
n=12\end{array}$ & $\begin{array}{c}91.6 \pm 20.0 \\
90.2 \\
61.9-135.9 \\
n=10\end{array}$ \\
\hline
\end{tabular}

11 with dSSc); lungs in 20/34 SSc patients (10 with 1 SSc and 10 with dSSc); heart in $15 / 34$ SSc patients ( 8 with $1 S S c$ and 7 with dSSc); osteoarticular changes in 27/34 SSc patients (15 with $15 S c$ and 12 with dSSc).

Cardiovascular changes were observed in 15 SSc patients ( 8 with $1 S S c$ and 7 with dSSc). They were of different character and developed as single events or coexisted with each other. Twenty-four-hour ECG monitoring showed a tendency to tachycardia. Mean heart rate in SSc patients was $81 \pm 11$ in comparison to $71 \pm 9$ observed in the control group. Conduction disturbances were found in 3 patients, 6 presented heart rhythm disturbances, and other 6 presented episodes of ischaemia. Statistically significantly lower values of 24-hour heart rhythm monitoring were observed in SSc patients in comparison to the control group. One patient presented late ventricular potentials. QT intervals were within normal limits. Cardiographic examination did not reveal any impairment of systolic function of the left ventricle in any of the examined patients; however 6 patients presented impairment of diastolic function of this ventricle. Eight patients presented organic changes such as fibrosis of the mitral valve leaflets and/or aortic cusps; however only in two patients the changes were of hemodynamic importance.

It was demonstrated that mean levels of VEGF were lower than those in the control group (194.0 \pm $196.8 \mathrm{pg} / \mathrm{mL}$ and $271.2 \pm 201.0 \mathrm{pg} / \mathrm{mL}$, respectively at $P>$ $.05)$; endostatin were higher than those in the control group $(113.6 \pm 60.7 \mathrm{ng} / \mathrm{mL}$ and $73.6 \pm 25.9 \mathrm{ng} / \mathrm{mL}$, respectively at $P<.05)$; and TIMP2 were not different from the control group $(80.0 \pm 31.5 \mathrm{ng} / \mathrm{mL}$ and $91.6 \pm 20.0 \mathrm{ng} / \mathrm{mL}$, respectively at $P>.05$ ) (Table 1 ). Using Fisher test, we did not find any statistically significant correlation between serum levels of the examined parameters and cardiovascular changes (detailed data not presented). However, comparison of mean serum levels of VEGF, endostatin, and TIMP2 in patients with heart involvement showed higher levels of endostatin than in the control 
TABLE 2. Correlations between vascular endothelial growth factor (VEGF), endostatin, and tissue inhibitor of metalloproteinases 2 (TIMP2) serum levels and heart involvement in the different groups examined (Fisher precisely test, coefficient $Q$ ); $n$ is the number of the patients; $P$ is the statistical significance at $P<.05$.

\begin{tabular}{|c|c|c|c|c|c|}
\hline Parameter & $\begin{array}{l}\text { Systemic sclerosis } \\
\text { (SSc)—whole group }\end{array}$ & $\begin{array}{l}\text { Limited systemic } \\
\text { sclerosis (1SSc) }\end{array}$ & $\begin{array}{l}\text { Diffuse systemic } \\
\text { sclerosis (dSSc) }\end{array}$ & $\begin{array}{l}\text { Systemic sclerosis in } \\
\text { selected patients } \\
\operatorname{sSSc}(n=14)\end{array}$ & $P$ \\
\hline VEGF (pg/mL) & -0.067 & 0.091 & -0.280 & -0.636 & $P=.245$ \\
\hline Endostatin (ng/mL) & 0.766 & 0.800 & 0.280 & 0.636 & $P=.245$ \\
\hline TIMP2 (ng/mL) & 0.474 & 1.000 & 0.675 & 0.000 & $P=.441$ \\
\hline
\end{tabular}

TABLE 3. Comparison of VEGF, endostatin, and TIMP2 serum levels in systemic sclerosis patients with or without heart involvement. (a1), (a2), and (a3) denote patients with heart involvement; (b1), (b2), and (b3) denote patients without heart involvement; SD is the standard deviation; $n$ is the number of patients.

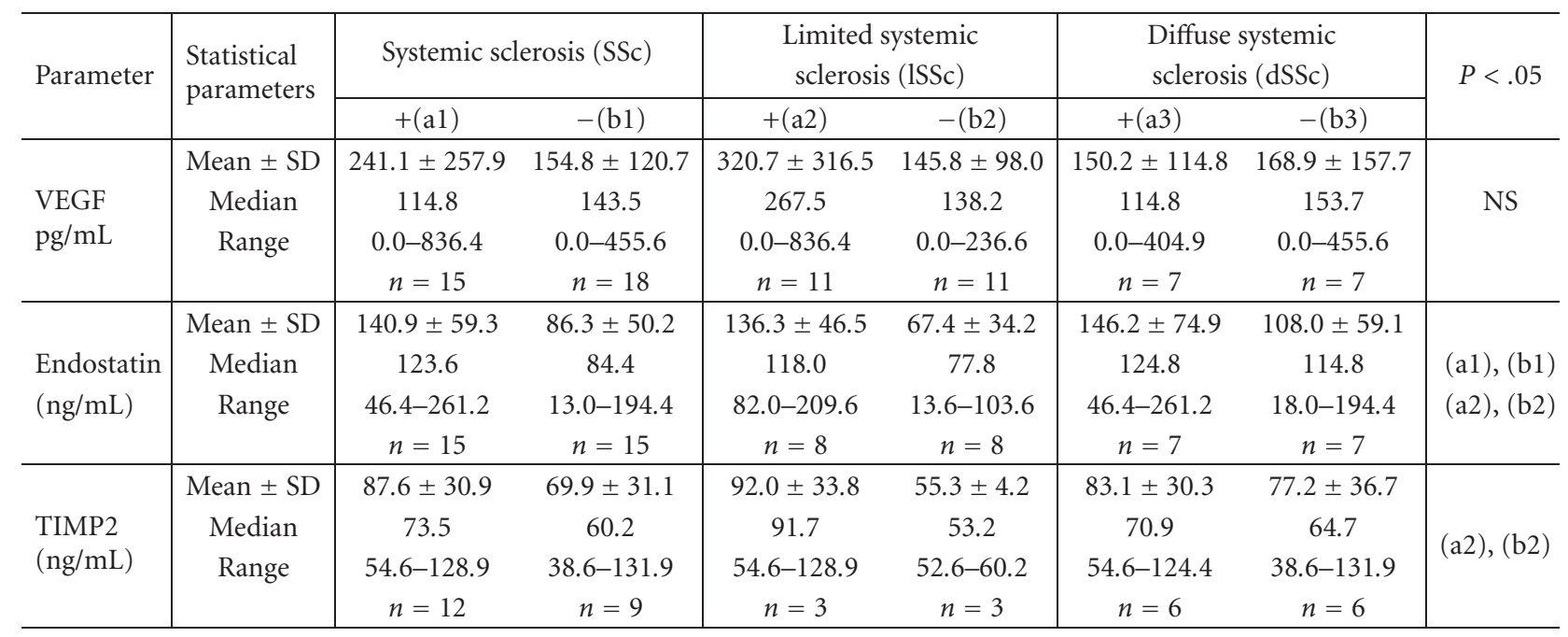

group $(P<.05)$; also such a tendency, however still statistically insignificant, was observed in the selected 14 SSc patients (sSSc), in whom all 3 substances were assessed (Table 2). It was also demonstrated that mean serum levels of endostatin and TIMP2 were statistically significantly higher in patients with heart changes than in the group of patients without such changes $(P<.05)$ (Table 3$)$.

Antinuclear antibodies (ANA) were found in 34 patients. In 19 patients with 1 SSc the following ANA were observed: anti-topoisomerase I (10 patients), U3RNP antibodies (1 patient), U1RNP antibodies (2 patients), antiRNA polimerase I antibodies (1 patient), and antinuclear antibodies of unidentifiable specificity ( 5 patients). In dSSc patients the following antinuclear antibodies were identified: anti-Scl 70 antibodies (10 patients, in two patients coexisted with anticentromere antibodies, ACA, and in one patient coexisted with $\mathrm{Ku}$ antibodies) and U3RNP (5 patients). No ACA antibodies were demonstrated in any of the examined patients.

\section{DISCUSSION}

Coronary vessel changes and fibrosis of the myocardium are features of heart involvement in the course of systemic sclerosis. Kucharz pointed out that heart involvement is often symptomless [19]. Myocardial fibrosis usually develops in subendocardial layer and does not depend on blood supply, as in atherosclerosis. Kucharz also revealed that ECG changes were observed in about $50 \%$ of systemic sclerosis patients [19]. Thickening of the left ventricular wall, asymmetrical hypertrophy of interventricular septum, cardiomegaly, and exudative changes in the pericardial sac have been described. Rodnan et al was the first group who demonstrated that apart from vessel spasms, inflammatory changes and fibrosis of coronary vessel walls were important factors in myocardial ischaemia development [25].

Endostatin is found in blood, urine, and basement membranes of many organs but its activity has not been fully elucidated [26]. However, it is known that endostatin specifically inhibits endothelial cell proliferation and migration stimulated by VEGF [27]. Endostatin also vastly reduces inflow of endothelial cells to newly developed basal membrane of the blood vessels [28]. In vitro, incubation of endostatin with endothelial cells leads to cell apoptosis [29].

Increased levels of endostatin were found in systemic sclerosis patients in comparison to the control group [30]. Our results demonstrated significantly increased serum endostatin levels in scleroderma patients when compared 
with the control group, too. Collagen type XVIII can be found in the basement membrane of skin blood vessels and internal organs involved in systemic sclerosis [31]. Other authors demonstrated increased endostatin serum levels only in a small group of patients; however they did not find any correlation with clinical parameters [32]. In SSc patients, especially with cardiovascular disturbances, TIMP2 and endostatin action could be dependent on tissue microenvironment. TIMP2 and endostatin may act synergistically exerting their antiangiogenic action via not yet fully elucidated pathways in SSc course. This action could be also triggered by the treatment methods employed and could further result from systemic response of the organism. However, despite not fully elucidated endostatin action, it could be assumed that this factor inhibits activation of proenzymatic metalloproteinase 2 form and catalytic actions of membrane metalloproteinases type 1 and type 2 [28]. Thus, endostatin exerts a considerable effect on accumulation of extracellular matrix components and fibrosis development in the internal organs. Our results point out statistically significantly increased endostatin levels in scleroderma patients presenting cardiovascular disturbances in comparison to the patients without such abnormalities. Probably increased levels of this factor may also lead to inhibitory effect of angiogenesis in anoxied heart tissue.

Tissue inhibitor of metalloproteinase 2 is a protein of $21-\mathrm{kd}$ molecular weight, released in a soluble form. This protein exerts an inhibitory effect on all active metalloproteinases forms and competes with them as regards regulation of the extracellular matrix amount [33]. Yazawa et al demonstrated statistically significantly increased serum levels of both TIMP1 and TIMP2 in SSc patients than in the control group [34].

The current study results did not reveal statistically significant differences as for TIMP2 serum levels between SSc patients and the control group. However, our results demonstrated statistically significant differences of this protein level in the serum of ISSc patients with/or without heart involvement. So, this observation could further support the importance of TIMP2 in the development of cardiovascular changes. Excessive accumulation of collagen type I could lead to heart muscle fibrosis and restrictions in the systo-diastolic function of the heart ventricles [35]. It can be further assumed that increased levels of TIMP2 may lead to angiogenesis inhibition, thus intensifying already triggered dysfunction of microcirculation [36]. Imbalance of heart extracellular matrix components and decreased number of capillaries could also lead to oxygen diffusion restrictions and myocyte hypoxia. Structural changes of heart walls probably result from imbalance between production and destruction of extracellular matrix components, proliferation and migration of cells and their apoptosis and necrosis. Heart fibroblasts take part in the above processes via production of growth factors and cytokines, which exert auto and paracrine action. Those cells also interfere with proteinases quantity and extracellular matrix composition. Thus, it seems reasonable to conclude that the currently observed correlation between TIMP2 levels and heart dysfunction may be much more important in disturbances of extracellular matrix degradation than ECM excessive accumulation.

The obtained results seem to confirm an important role of angiogenic and fibrotic factors in the course of systemic sclerosis, including development of cardiovascular disturbances. They also suggest that evaluation of endostatin and TIMP2 serum levels in SSc patients could be helpful in the assessment of the cardiovascular system.

\section{ACKNOWLEDGMENT}

This work was supported by Personal Grant no 50211-697 from the Medical University of Lodz.

\section{REFERENCES}

[1] Goetz RH. Pathology of progressive systemic sclerosis with special reference to changes in the viscera. Clin Proc (S Africa). 1945;4:337-342.

[2] Stone JH, Wigley FM. Management of systemic sclerosis: the art and science. Semin Cutan Med Surg. 1998;17(1):55-64.

[3] Steen VD, Medsger TA Jr. Severe organ involvement in systemic sclerosis with diffuse scleroderma. Arthritis Rheum. 2000;43(11):2437-2444.

[4] Black CM. The aetiopathogenesis of systemic sclerosis. J Intern Med. 1993;234(1):3-8.

[5] Josko J, Gwozdz B, Jedrzejowska-Szypulka H, Hendryk S. Vascular endothelial growth factor (VEGF) and its effect on angiogenesis. Med Sci Monit. 2000;6(5):1047-1052.

[6] Pepper MS. Manipulating angiogenesis. From basic science to the bedside. Arterioscler Thromb Vasc Biol. 1997;17(4):605-619.

[7] Park CC, Morel JC, Amin MA, Connors MA, Harlow LA, Koch AE. Evidence of IL-18 as a novel angiogenic mediator. J Immunol. 2001;167(3):1644-1653.

[8] Kaminski MJ, Majewski S, Jablonska S, Pawinska M. Lowered angiogeneic capability of peripheral blood lymphocytes in progressive systemic sclerosis (scleroderma). J Invest Dermatol. 1984;82(3):239-243.

[9] Koch AE, Litvak MA, Burrows JC, Polverini PJ. Decreased monocyte-mediated angiogenesis in scleroderma. Clin Immunol Immunopathol. 1992;64(2):153-160.

[10] Yazawa N, Kikuchi K, Ihn H, et al. Serum levels of tissue inhibitor of metalloproteinases 2 in patients with systemic sclerosis. J Am Acad Dermatol. 2000;42(pt 1):70-75

[11] Saarialho-Kere U, Kerkela E, Jahkola T, Suomela S, Keski-Oja J, Lohi J. Epilysin (MMP-28) expression is associated with cell proliferation during epithelial repair. J Invest Dermatol. 2002;119(1):14-21.

[12] Fini ME, Cook JR, Mohan R, Brinckerhoff CE. 
Regulation of matrix metalloproteinase gene expression. In: Parks WC, Mecham, RP, eds. Matrix Metalloproteinases. New York, NY: Academic Press; 1998:299-356.

[13] Bogaczewicz J, Chodorowska G, Krasowoska D. Role of matrix metalloproteinases and their tissue inhibitors in scleroderma [in Polish]. Przegl Dermatol. 2003;5:373-381.

[14] Greene J, Wang M, Liu YE, Raymond LA, Rosen C, Shi YE. Molecular cloning and characterization of human tissue inhibitor of metalloproteinase 4. J Biol Chem. 1996;271(48):30375-30380.

[15] Wynn J, Fineberg N, Matzer L, et al. Prediction of survival in progressive systemic sclerosis by multivariate analysis of clinical features. Am Heart J. 1985;110(pt 1):123-127.

[16] Follansbee WP. Organ involvement: cardiac. In: Clements PJ, Furst DE, eds. Systemic Sclerosis. Baltimore, Md: Wiliams \& Wilkins; 1996:333-364.

[17] Valentini G, Maione S. Cardiopathy in systemic sclerosis. Recenti Prog Med. 1996;87(11):557-563.

[18] Mitchell H, Bolster MB, LeRoy EC. Scleroderma and related conditions. Med Clin North Am. 1997;81(1):129-149.

[19] Kucharz EJ. Heart lesions in patients with systemic sclerosis [in Polish]. Pol Arch Med Wewn. 1997;97(1):1-6.

[20] D'Angelo WA, Fries JF, Masi AT, Shulman LE. Pathologic observations in systemic sclerosis (scleroderma). A study of fifty-eight autopsy cases and fiftyeight matched controls. Am J Med. 1969;46(3):428440.

[21] Wranicz K, Zielinska M, Cygankiewicz I, Dziankowska-Bartkowiak B, Sysa-Jedrzejowska A. Early cardiovascular involvement in patients with systemic sclerosis (SSc). Med Sci Monit. 2002;8(2):CR78-82.

[22] Zabinska-Plazak E, Wojas-Pelc A, Plazak W, Bogdaszewska-Czabanowska J, Tracz W. Heart rhythm disturbances and variability of heart rhythm in scleroderma patients [in Polish]. Przegl Dermatol. 2003;4:251-258.

[23] Subcommittee for Scleroderma Criteria of the American Rheumatism Association Diagnostic and Therapeutic Criteria Committee. Preliminary criteria for the classification of systemic sclerosis (scleroderma). Arthritis Rheum. 1980;23(5):581-590.

[24] Kahaleh MB. Soluble immunologic products in scleroderma sera. Clin Immunol Immunopathol. 1991;58(1):139-144.

[25] Rodnan GP, Myerowitz RL, Justh GO. Morphologic changes in the digital arteries of patients with progressive systemic sclerosis (scleroderma) and Raynaud phenomenon. Medicine (Baltimore). 1980;59(6):393-408.

[26] Sasaki T, Fukai N, Mann K, Gohring W, Olsen BR, Timpl R. Structure, function and tissue forms of the
C-terminal globular domain of collagen XVIII containing the angiogenesis inhibitor endostatin. EMBO J. 1998;17(15):4249-4256.

[27] O'Reilly MS, Boehm T, Shing Y, et al. Endostatin: an endogenous inhibitor of angiogenesis and tumor growth. Cell. 1997;88(2):277-285.

[28] Kim YM, Jang JW, Lee OH, et al. Endostatin inhibits endothelial and tumor cellular invasion by blocking the activation and catalytic activity of matrix metalloproteinase. Cancer Res. 2000;60(19):5410-5413.

[29] Dixelius J, Larsson H, Sasaki T, et al. Endostatininduced tyrosine kinase signaling through the Shb adaptor protein regulates endothelial cell apoptosis. Blood. 2000;95(11):3403-3411.

[30] Hebbar M, Peyrat JP, Hornez L, Hatron PY, Hachulla E, Devulder B. Increased concentrations of the circulating angiogenesis inhibitor endostatin in patients with systemic sclerosis. Arthritis Rheum. 2000;43(4):889-893.

[31] Halfter W, Dong S, Schurer B, Cole GJ. Collagen XVIII is a basement membrane heparan sulfate proteoglycan. J Biol Chem. 1998;273(39):25404-25412.

[32] Distler O, Del Rosso A, Giacomelli R, et al. Angiogenic and angiostatic factors in systemic sclerosis: increased levels of vascular endothelial growth factor are a feature of the earliest disease stages and are associated with the absence of fingertip ulcers. Arthritis Res. 2002;4(6):R11.

[33] Mattila L, Airola K, Ahonen M, et al. Activation of tissue inhibitor of metalloproteinases-3 (TIMP-3) mRNA expression in scleroderma skin fibroblasts. $J$ Invest Dermatol. 1998;110(4):416-421.

[34] Yazawa N, Kikuchi K, Ihn H, Fujimoto M, Kubo M, Tamaki T. Serum levels of tissue inhibitor of metalloproteinases 2 in patients with systemic sclerosis. $J$ Am Acad Dermatol. 2000;42(pt 1):70-75.

[35] Manabe J, Shindo T, Nagai R. Gene expression in fibroblasts and fibrosis: involvement in cardiac hypertrophy. Circ Res. 2002;91:1103-1113.

[36] Szary J, Szala S. Endostatin in neoplasm therapy [in Polish]. Nowotwory J Oncol. 2002;52:159-164. 


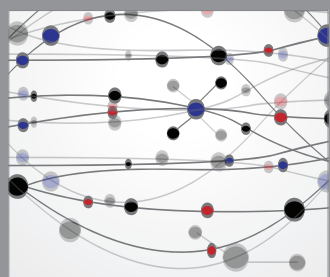

The Scientific World Journal
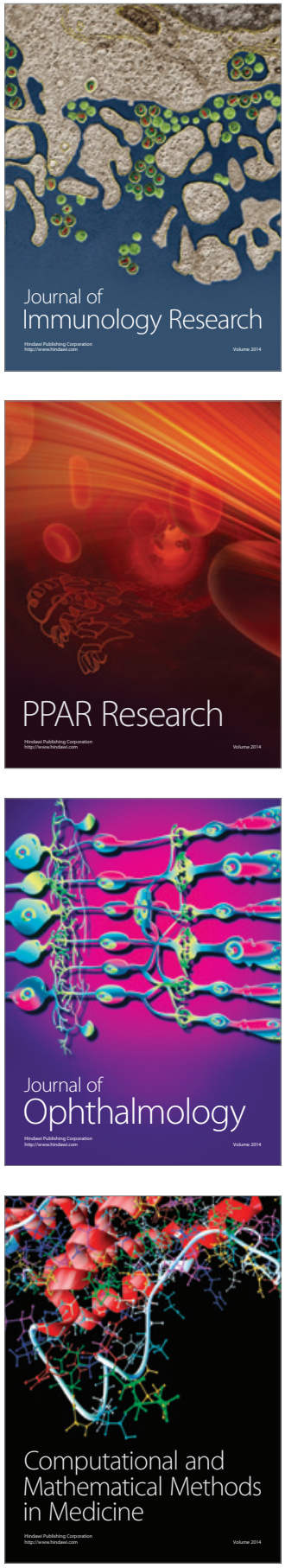

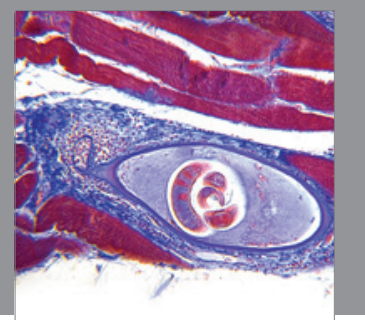

Gastroenterology

Research and Practice
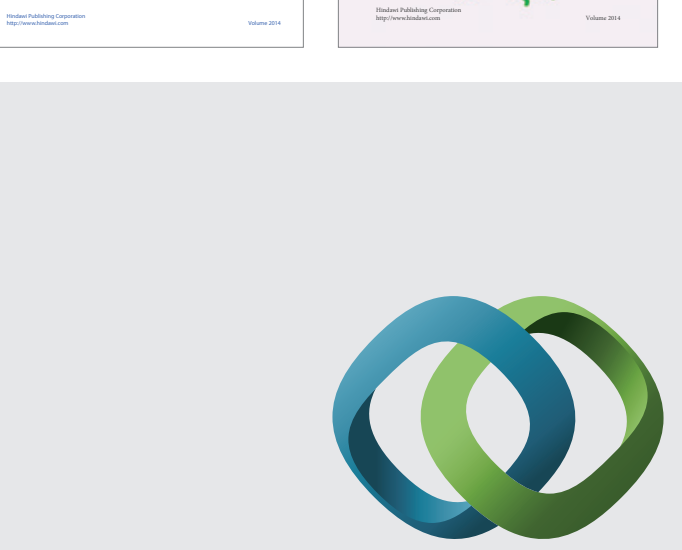

\section{Hindawi}

Submit your manuscripts at

http://www.hindawi.com
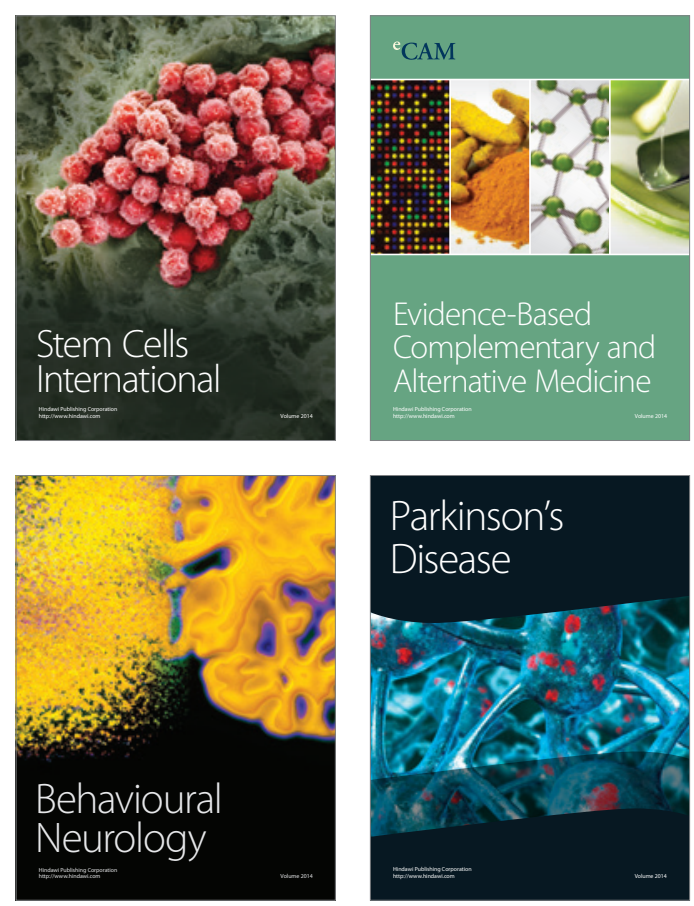

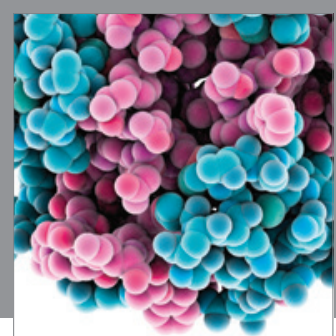

Journal of
Diabetes Research

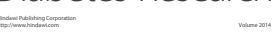

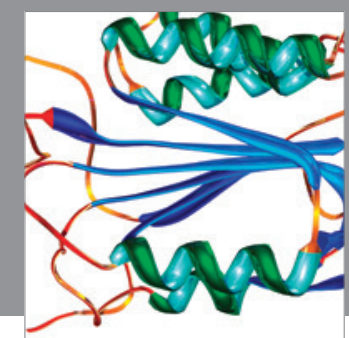

Disease Markers
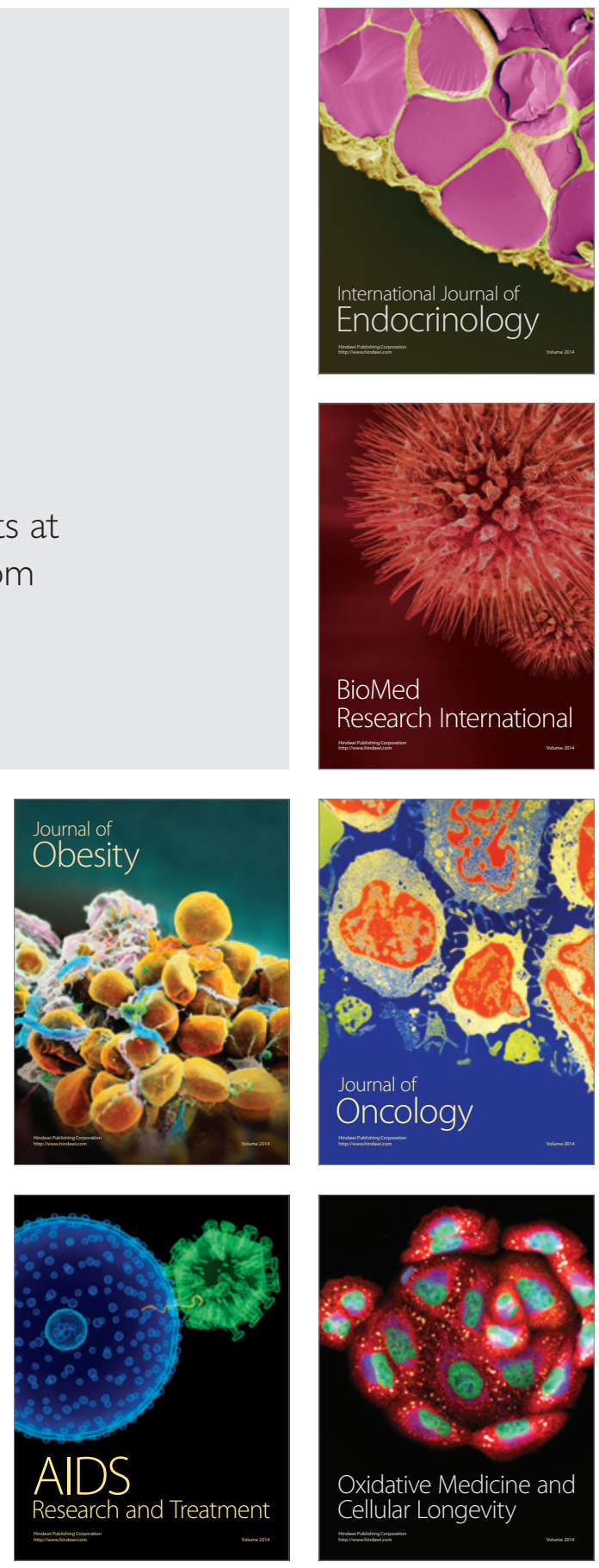